\title{
Legemøter - alltid like seriøse?
}

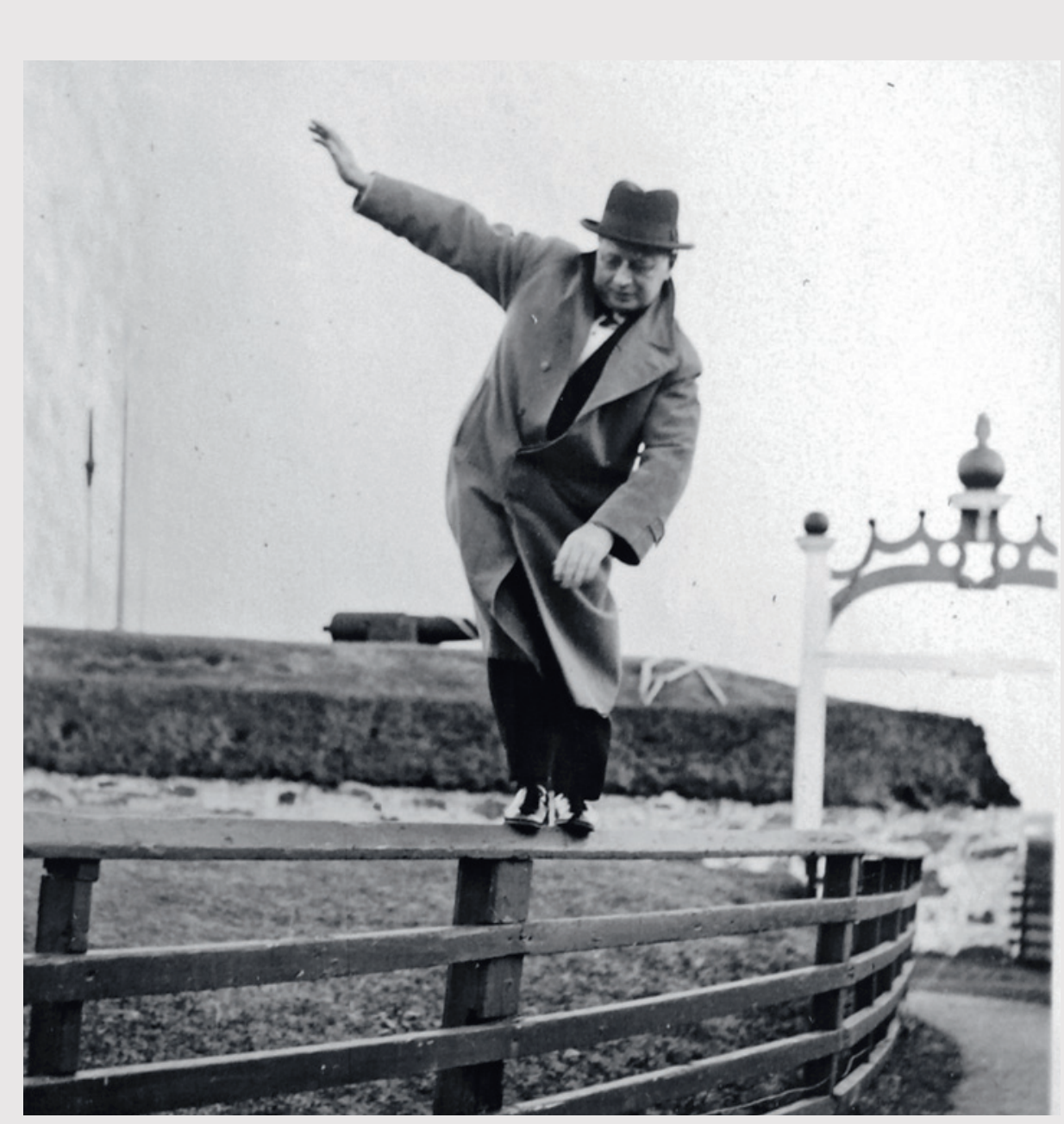

Foto Sverre Sørsdal

Kurs og møter står på kalenderen til de fleste norske leger. Vi er vant til å møtes for å lære, bli oppdatert og utveksle erfaringer. I Norge finner vi de første spirene til slik organisert møtevirksomhet og informasjonsutveksling i 1820-årene.

Fra 1830-årene fikk vi også internasjonale møter og kongresser, og etter hvert ble det vanlig med reiser til kurs og møter eller studieopphold i utlandet.

Systematisk kursvirksomhet for leger, slik vi kjenner det, er imidlertid forholdsvis nytt. Det begynte etter den annen verdenskrig, og det faste kursopplegget som alle nålevende leger er vant til, stammer fra 1960-årene.

Før var det i større grad nødvendig med eget initiativ. Sannsynligvis var informa- sjonsbehovet særlig stort hvis man bodde og arbeidet langt ute i norsk periferi.

Kirurgen Sverre Sørsdal (1900-96) var overlege ved Vardø sykehus mer eller mindre sammenhengende fra 1934 til 1952. Vardø i 1930-årene var forholdsvis isolert, i hvert fall medisinsk. Da krigen kom, ble det verre. I en periode i 1944-45 hadde man verken rutebåt- eller veiforbindelse, post eller noenlunde fungerende telefon. I tillegg var overlegens medisinske bøker gått tapt i krigshandlingene.

Men i 1936 var det fortsatt normalt og rolig. Da var det legemøte i Vardø. Hvor mange de var, og hva temaene var, er ukjent, men den ivrige amatørfotografen dr. Sørsdal tok bilder. Møtets fest fant åpenbart sted på Vardøhus festning.
Vi vet ikke hvilken kollega det er som i den anledning balanserer på rekkverket i festantrekk og lakksko.

Det er kanskje like greit.

\section{Øivind Larsen}

oivind.larsen@medisin.uio.no

Øivind Larsen (f. 1938) er professor emeritus ved Institutt for helse og samfunn, Universitetet i Oslo.

Ingen oppgitte interessekonflikter.

Mottatt 3.11. 2011 og godkjent 10.112011. Medisinsk redaktør Anne Kveim Lie. 